\title{
29. PECULIARITIES OF MESO-CENOZOIC SEDIMENTATION IN THE BAY OF BISCAY AND ROCKALL PLATEAU REGIONS, LEG 48
}

\author{
P.P. Timofeev, N.V. Rengarten, and V.V. Eremeev, Geological Institute of the USSR Academy of Sciences, Moscow
}

\section{INTRODUCTION}

During the last 15 to 20 years, the fields of lithology and sedimentary chemistry have experienced significant development and expanded interest. As scientific knowledge in these fields is accumulated and applied, new solutions are being offered in response to the cardinal problems of the origin, compositional formation, and structural regularities of sedimentary rocks.

These advances were achieved through complex methods of detailed lithofacies and paleogeographical analyses applied to the study of both Recent sediments and older rocks. Of paramount importance is the use of all current methods of physical and chemical investigation of the composition of sediments and rocks. These studies enable recognition of the peculiarities and details of the genesis of deposits (sedimentogenesis) in order to establish the major factors and causes determining the history of mineral transformation of sediments into rocks (lithogenesis).

The study of the accumulation of Mesozoic and Cenozoic deposits from Holes 400/400A, 401, and 402/402A in the Bay of Biscay, and from Sites 403, 404, 405, and 406 on Rockall Plateau was based on the complex method of detailed lithofacies analysis (Timofeev, 1968). The main task of this method is distinguishing genetic and facial types of sediments. In the course of describing sediments and rocks in detail, one can distinguish the primary (genetic) and secondary features (acquired in the process of sediment-to-rock transformation). This complex of features serves as the basis for determining the lithological types of sediments (rocks), the nomenclature of which reflects their structure and composition. From among the variety of features, one can single out genetical (primary) characteristics that enable specification of the conditions of sediment accumulation. Various combinations of genetic features which determine the characteristics of sediments serve as the basis for distinguishing an elementary genetic unit of a section, i.e., a genetic type of sediment. "Genetic type" of sediments means one or more lithological types of sediments (rocks) characterized by a combination of allied genetic (primary) features reflecting the common conditions of their accumulation.

The further study of distribution of genetic types of sediments (sectionally and areally) allows elucidation of the physical-geographical (paleogeographical) conditions of their accumulation, i.e., allows reconstruction of the sedimentation environment. A "facies" is such an elementary paleogeographical unit. "Facies" (i.e., facies type of a sediment) denotes not only a complex of physical-geographical conditions in the sedimentation environment that resulted in formation of allied genetic types of sediments, but also denotes the sediments themselves which possess a corresponding complex of primary (genetic) features (conditions + sediment). The facies are presented in this report as an elementary geological body with space and time parameters.

Each separate facies characterizes rather limited sectors of the sedimentation area. Therefore, an analysis of space distribution of facies and, especially, the peculiarities of conjugation with adjacent facies makes it possible to characterize vast areas of terrain in terms of a certain syngenetic tectonic regime. This complex of conjugated facies, corresponding to vast areas, is termed a "macrofacies."

This report presents a brief summary of the principles of methods of detailed lithofacies study of sedimentary rocks. A complete description of the methods is given in the papers by Timofeev $(1969,1970,1972)$.

The above-referenced technique not only enables us to elucidate a detailed genesis of Recent and older sediments, as well as decipher the processes of sedimentogenesis (of sediments) and lithogenesis (of rocks), but also serves as the basis for recognition of the history of sedimentation and geological development of oceanic and continental blocks of the Earth's crust, hence, for establishing global correlation of geological processes of sedimentary rock formation of the Earth's crust.

\section{BRIEF SUMMARY OF LITHOFACIES CHARACTERISTIC OF THE BAY OF BISCAY AND ROCKALL PLATEAU}

The structure of Mesozoic-Cenozoic deposits for the Bay of Biscay and Rockall Plateau are illustrated for each hole under study in Figures 1 through 7 and in Plates 1 through 4. On the right side of each of these figures is presented the subdivision into units adopted by the Shipboard Party of Leg 48. Additionally two diagramatical facies sections, presented in Figures 8 and 9, show interrelations of both the facies and the macrofacies complexes, reflecting the history of sediment formation and geological development of the Bay of Biscay and Rockall Plateau regions.

\section{The Bay of Biscay}

The sedimentary pile in the Bay of Biscay has been penetrated at Sites $309,400,401$, and 402 . This report focuses on data from the latter two sites wherein a wide age range, from Late Jurassic to Pleistocene, is represented. However the stratigraphic column is not complete; breaks in sedimentation (local and regional washouts) are common, with Cretaceous sediments being especially poorly 


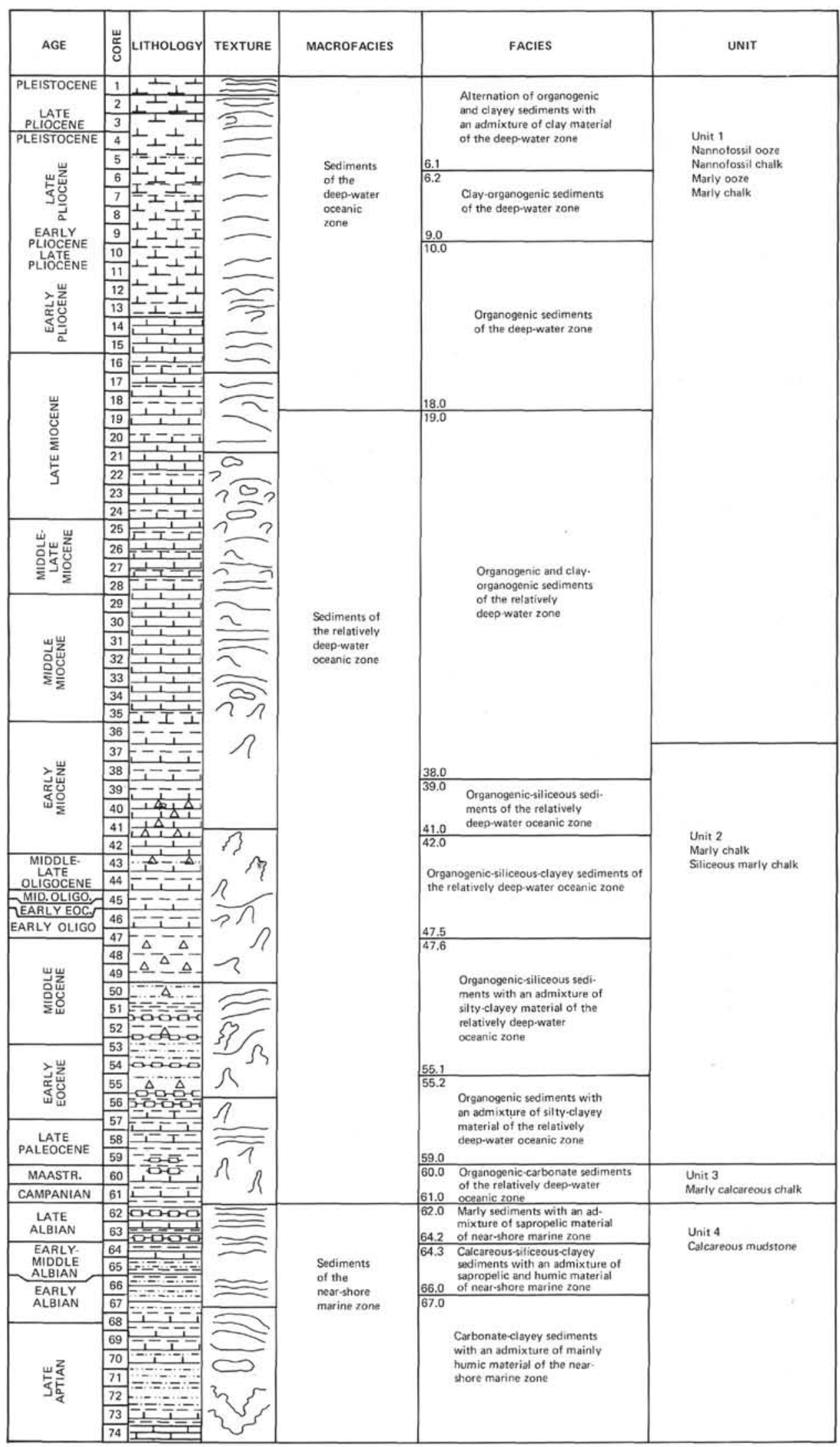

Figure 1. Lithological facial section, Holes 400 and 400A, Leg 48. 


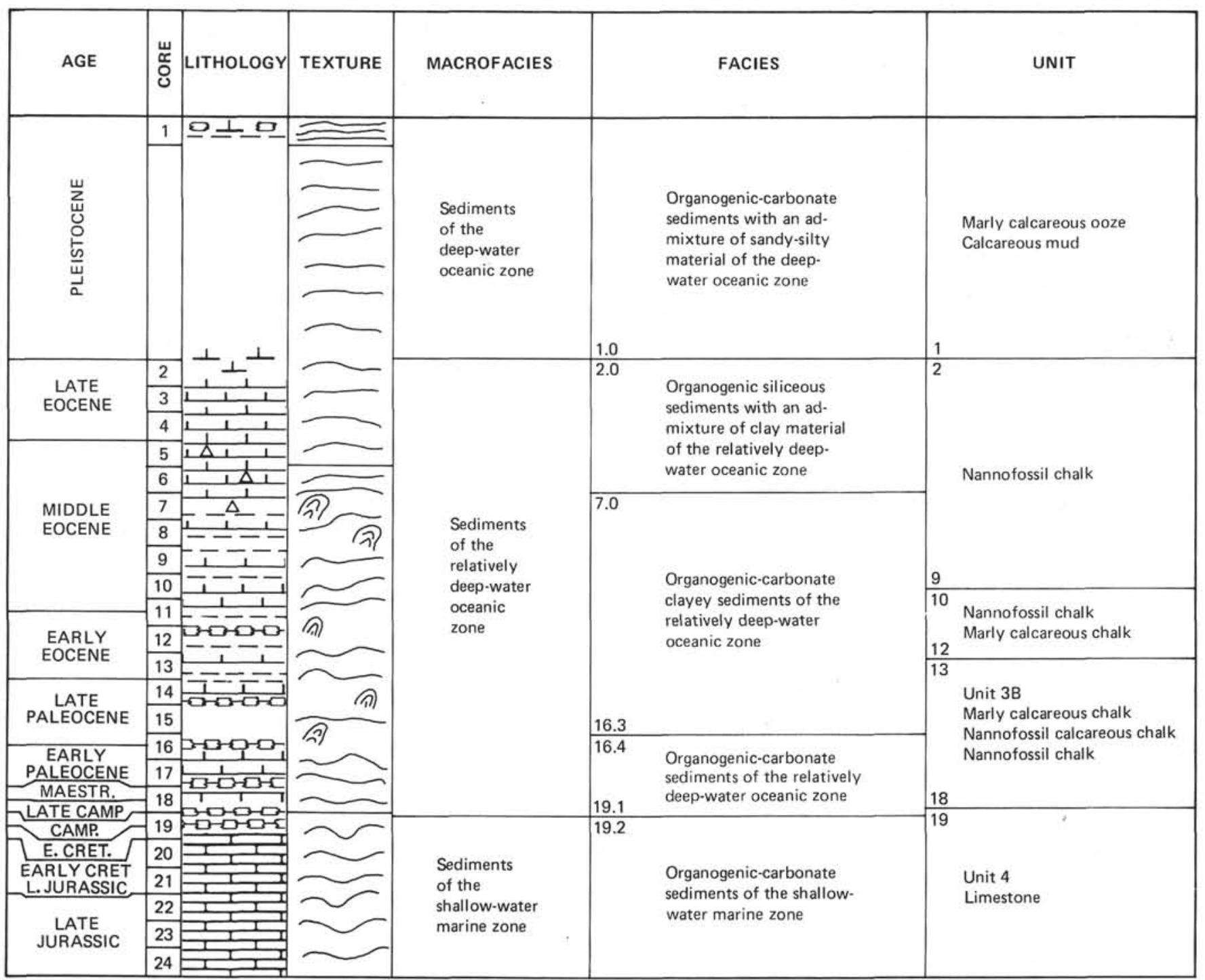

Figure 2. Lithological facial section, Hole 401, Leg 48.

preserved. Paleogene and Neogene deposits are nearly complete in Holes 400/400A.

The following paragraphs describe the sedimentary deposits for each age interval.

\section{Jurassic Deposits}

Upper Jurassic: Jurassic deposits were penetrated only at Site 401 (Cores 20 to 24; Figure 1). They consist of white (pinkish in interbeds), hard, usually massive limestones. Obscure horizontal and horizontally wavy lamination and, in places, sporadic burrows, can be observed. The limestones are organogenic-detrital with micro-pelloidal texture. They contain fragments of echinoderm columnals, mollusk shells, foraminiferal tests, and pieces of carbonate algae. The cement is calcareous, sometimes pelitomorphic, slightly arenaceous, sometimes inequigranular (i.e., recrystallized). Peculiar to these rocks is their micro-pelloidal structure. Pellets of pelitomorphic carbonate, which is the dominant component in these samples, are of varied sizes, oval and isometric in shape, clearly contoured in places, and sometimes with diffuse margins. Within larger pellets there are visible remains of calcareous organisms; in smaller ones, relics of foraminiferal tests occur on occasion. The nuclei in some pellets are composed of granular calcite. Noteworthy is that some relatively large remains of echinoderms and fragments of mollusk shells are not "rolled up" into pelitomorphic pellets, but covered with a thin carbonate sheet. In these cases, traces of decomposition by boring algae can be found. Interbeds of rocks occur in which calcareous pellets are rounded and sorted according to their size, being cemented by secondary granular calcite. These rocks are calcareous-cluster sandstones (pelletic calcarenite). Following the work of Khvorova (1958), we explain the origin of the lumpy structure of the sediments under study as a result of activity of mudeaters and algae. Strakhov (1951) states that these pellets may result from partial decomposition of foraminiferal tests.

The lumpy structure of limestones and carbonate organic remains pitted by algae, indicating that the sediments 


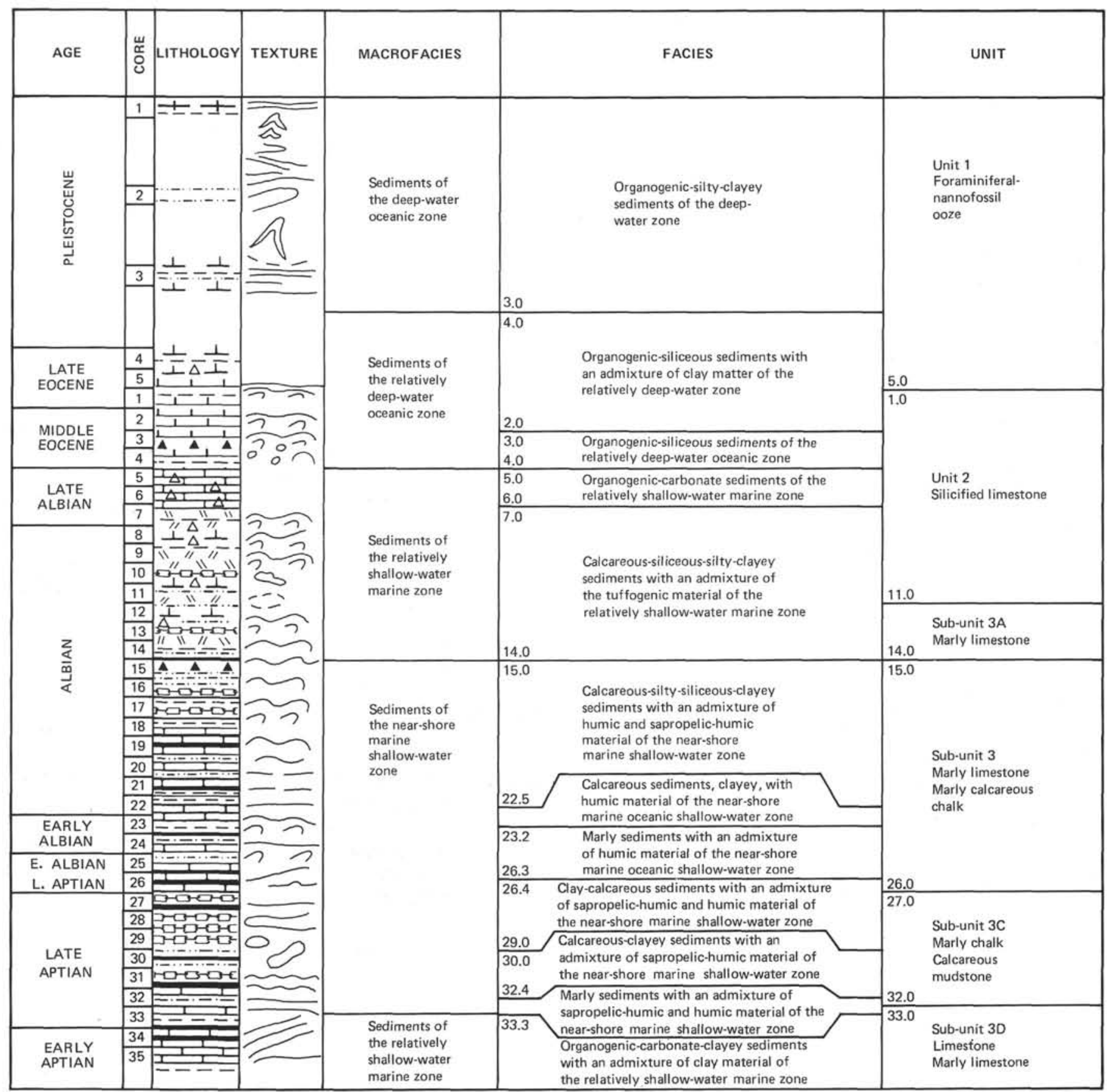

Figure 3. Lithological facial section, Holes 402 and 402A, Leg 48.

accumulated in shallow-water $(\approx 100 \mathrm{~m})$. These sediments belong to the macrofacies of the shallow-water zone of marine sedimentation.

\section{Cretaceous Deposits}

Aptian-Albian: Deposits of this age are recognized in sections from Sites 400 and 402; no deposits were found at Site 401. At Site 400 (Figure 2; Plate 1, Figures 2 and 3), Cretaceous deposits (Cores 62 to 74 ) are entirely assigned to the so-called series of "black shales" and characterize the macrofacies of sediments of the near-shore marine sedimentation zone. At Site 402 (Figure 3; Plate 1, Figure
1), the age interval of the "black shales" is from the upper Aptian to the middle of the Albian (Core 15 to Section 33-2). This series of true "black shales" was formed under conditions of the shallow-water near-shore marine sedimentation zone. Organogenic-carbonate-clayey sediments (Section 33-3 to Core 35) underlying the series accumulated in the macrofacies of a relatively shallow-water sea zone. The "black shales" series has been thoroughly studied by Timofeev and Bogolyubova (both, this volume).

Higher in the drilled intervals at Site 400 (Figure 1; Plate 2, Figure 2), the "black shales" series is overlain by 


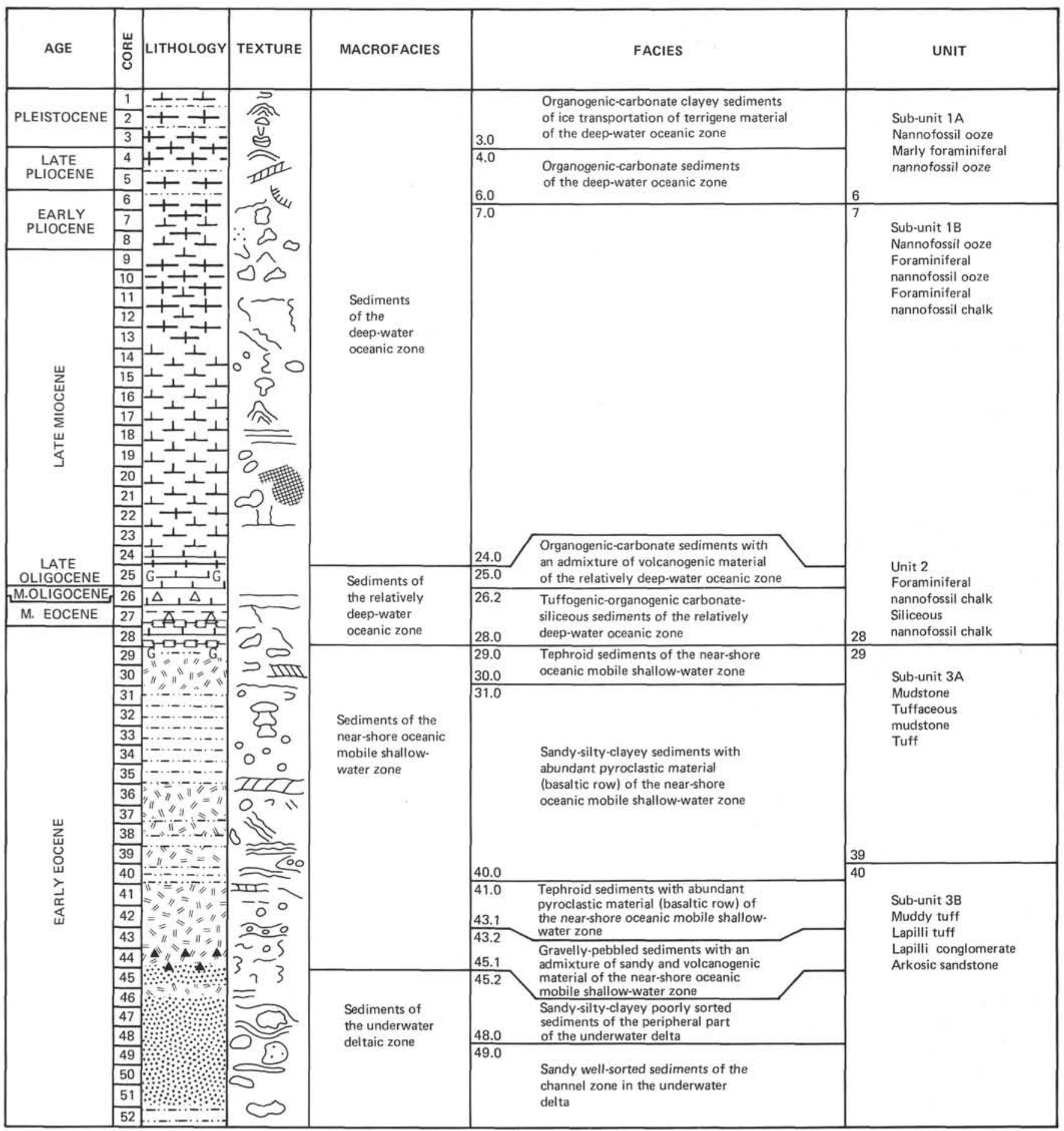

Figure 4. Lithological facial section, Hole 403, Leg 48.

tuffogenous organogeno-carbonate-siliceous deposits of Albian age. They are composed of dark gray thin-plated, hard (secondarily silicified) rocks with sponge spicules, foraminiferal tests, radiolarians, diatoms, echinoderms, indefinable shell detritus, fragments of calcareous algae, and volcanic glass cemented by pelitomorphic carbonate and globular opal. The lower part of the deposits of this series (Cores 5 to 14) also contains fragments of charred plant remains, patches of colloidal humic matter and a small admixture of silty (quartz, mica, feldspars) and clay particles. Higher in these holes, both the humic and organic matter and the silty-clayey admixture gradually disappear. Authigenic zeolite and montmorillonite can be observed throughout the section. In places, fragments of volcanic glass are replaced by calcite. The rocks are especially strongly silicified in some interbeds, with organogenic remains (radiolarians, spicules, calcareous shells, etc.) represented only by feeble relics. The whole mass of opal in 


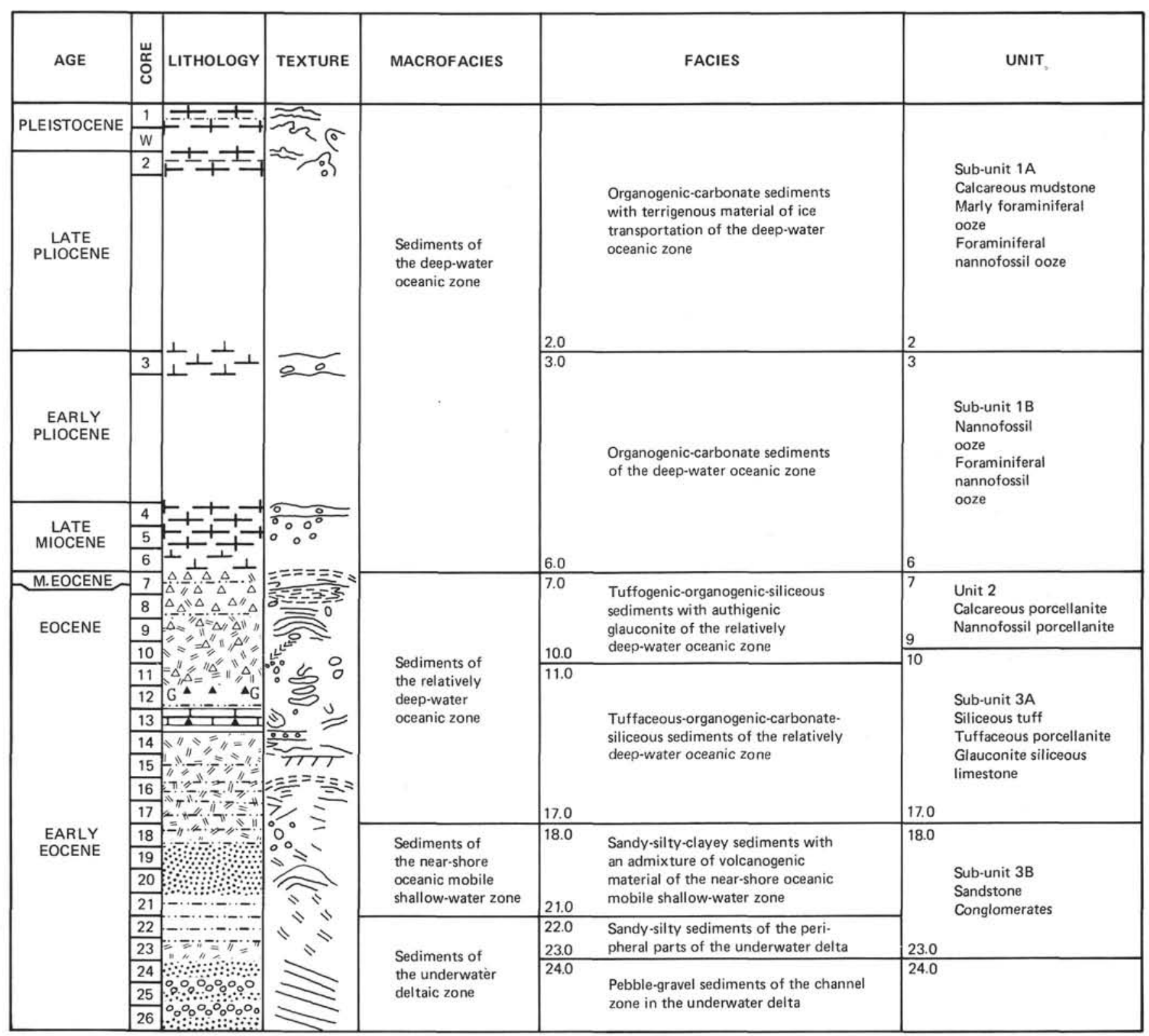

Figure 5. Lithological facial section, Hole 404, Leg 48.

these interbeds has been transformed into cristobalite. By the conditions of their accumulation, these deposits are attributed to the macrofacies of sediments of a relatively shallow-water marine sedimentation zone.

Campanian and Maestrichtian: Deposits of this age were recorded at Sites 400 (Cores 60 and 61) and 401 (Core 18 to Section 19-1). At both sites, the stratigraphic record shows an obvious stratigraphic break: at Site 400 on the washed-out surface of the Albian series; at Site 401, on the eroded surface of Upper Jurassic limestones. The thickness of Campanian/Maestrichtian deposits is insignificant $(\approx 12)$ to $18 \mathrm{~m}$ ). The deposits are pale, almost white, sometimes pinkish, very hard (strongly lithified) pelitomorphic limestones. In the ground fine-grained mass of carbonate, some relics of coccoliths can be observed, with foraminiferal tests and indefinable shell detritus recognized as well.
Remains of siliceous organisms are very rare. Clearly, the initial sediments of these limestones were nannofossil oozes, the accumulation of which should be related to the macrofacies of the relatively deep-water oceanic zone under conditions of deposition of mostly carbonate organogenic material; the supply or organogenic silica is insignificant.

\section{Paleogene and Neogene Deposits}

The oldest Paleogene deposits (lower Paleocene) were found only in Hole 401 (Section 16-4 to Core 17). These deposits are hard, gray and pinkish, pelitomorphic limestones with horizontal and horizontally wavy lamination, occurring locally with obscure micro-pelloidal texture. The fine-grained groundmass of carbonate contains remains of coccoliths, tests of foraminifers, and sporadic 


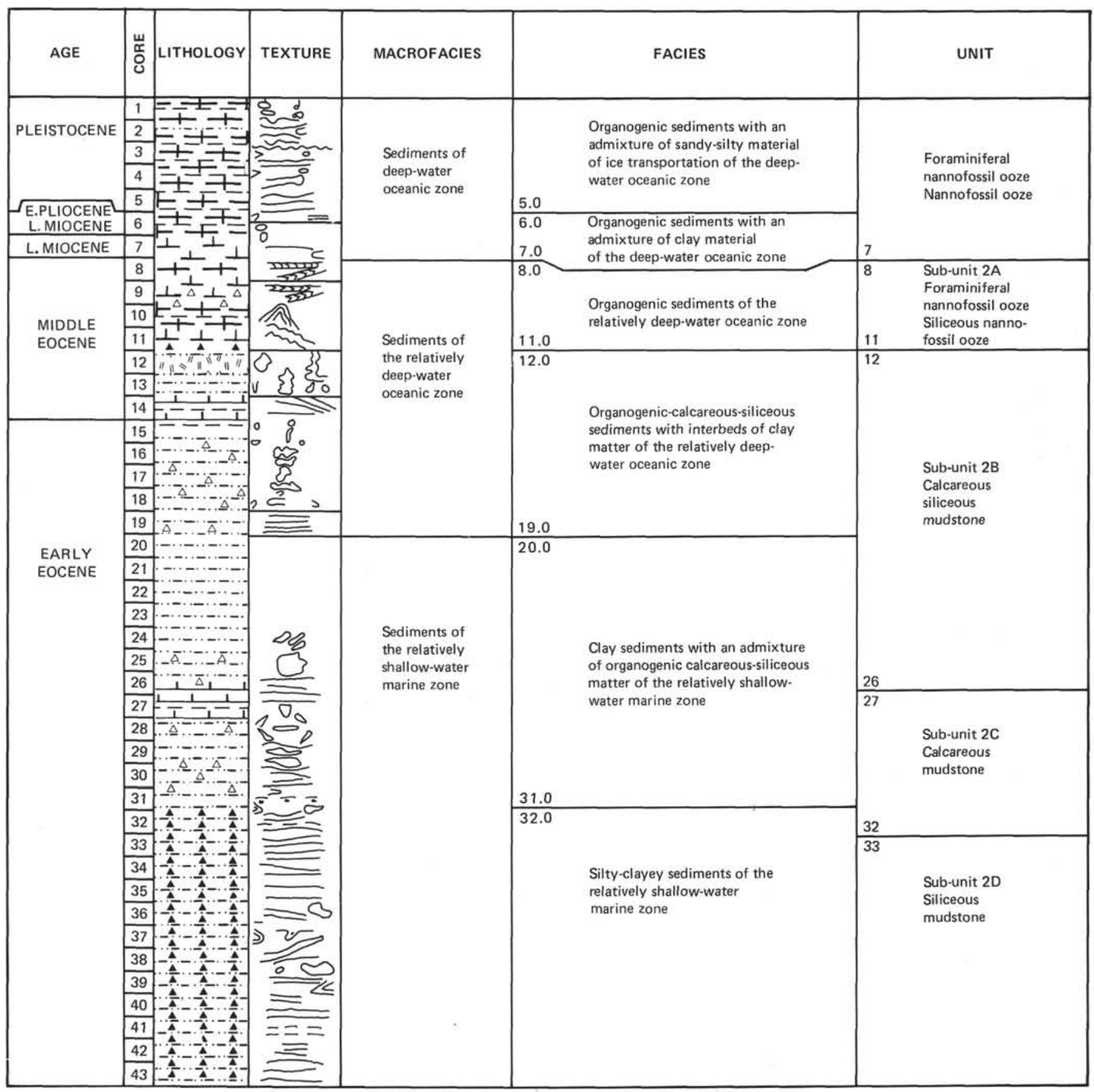

Figure 6. Lithological facial section, Hole 405, Leg 48.

remains of siliceous organisms. The rocks are associated with Maestrichtian deposits by a gradual transition, and belong to the same macrofacies of the relatively deep-water oceanic sedimentation zone under conditions of deposition of mostly carbonate organogenic material with an insignificant supply of organogenic material. No middle Paleocene deposits were recognized throughout the section.

At Site 400, directly above Maestrichtian deposits, there lies a nearly stratigraphically complete series of deposits, beginning from the upper Paleocene and ending in Pleistocene; upper Eocene and middle Pliocene sediments were not recorded. Two successive macrofacies of sediments are distinguished in the upper PaleocenePleistocene interval. Deposits of the lower macrofacies are attributed to the zone of relatively deep-water oceanic sedimentation, whereas the upper one is associated with the deep-water zone.

The macrofacies of the relatively deep-water sedimentation zone, under conditions of considerable and periodically abundant supply of organogenic silica at Site 400 (Cores 59 to 19) is subdivided into several facies. Each facies reflects the pecularities of their compositional 


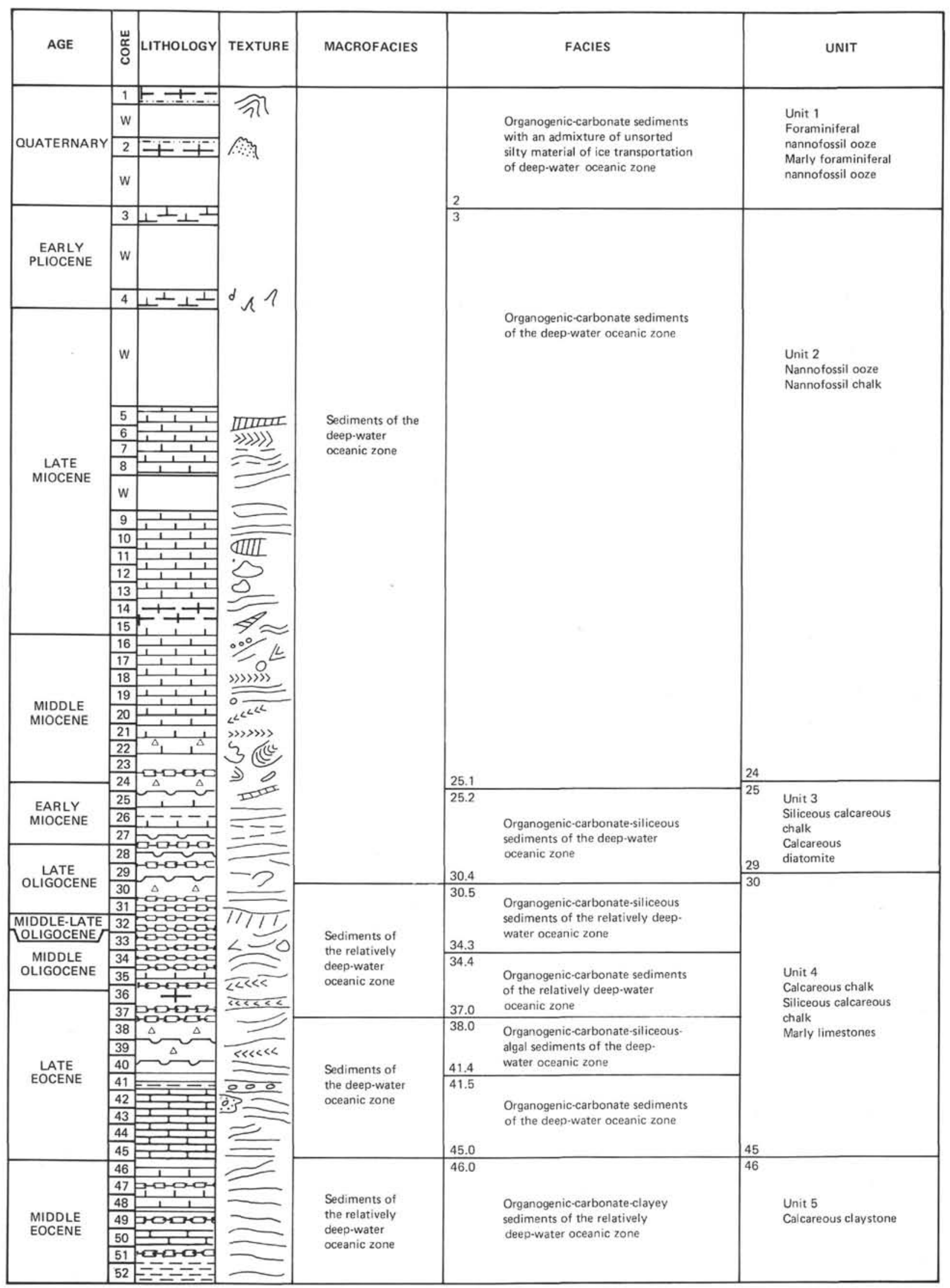

Figure 7. Lithological facial section, Hole 406, Leg 48. 
sediments (Figure 1). Although the deposits of conjugate facies are associated by gradual transitions, tentative age boundaries can be outlined for each facies.

Upper Paleocene and lowermost Eocene deposits (Core 59 to Section 55-2) are greenish and pinkish, hard pelitomorphic limestones; their primary sediments are clayey nannofossil oozes. Relics of coccoliths and rare foraminiferal tests remained preserved in the fine-grained carbonate mass with a small admixture of remains of siliceous organisms: radiolarians, diatoms, and sponge spicules (the number of the latter increasing upwards in the section). In some interbeds of limestones, there is an appreciable admixture of silt-sized quartz grains, mica, and feldspars. Authigenic zeolite is abundant throughout, developed in tests of foraminifers, and yields pseudomorphs after remains of siliceous organisms.

The upper half of the lower and middle Eocene (Sections 55-1 to 47-6), are greenish, without pink tints, clayey diatomites with relics of coccoliths and an admixture of volcanic glass. Also present are thin siliceous sponge spicules, the number of which increases upwards in the section, with their isolated accumulations (balls) becoming more frequent. Tests of foraminifers are rare, zeolite tests are constant. In places with an appreciable admixture of vitroclastic material, authigenic montmorillonite (clusters) is observed. Small lenses of clay matter are occasionally present, elongated along the lamination of sediments.

\section{Oligocene and Lower Part of Middle Miocene} (Hole 400A, Section 47-5 to Core 19)

These deposits (Plate 3, Figure 1) are light greenish gray nannofossil oozes with fragments of thin spicules of siliceous sponges, rare diatom skeletons, tests of foraminifers, and sporadic silty particles of quartz. Higher in this interval, the number of siliceous spicules gradually increases, and there appear interbeds of spongolites with coccolithic cement. In sediments of this facies, there are microbreccias consisting of pieces of limestones, marls, and green clay. The primary lamination is obscure, probably slightly horizontal.

In Hole 401 (Figure 2; Plate 3, Figure 2), the Paleogene is represented by analogous deposits. The Paleogene interval is incomplete, beginning with the upper Paleocene and including the entire Eocene. Foraminiferal/nannofossil oozes (with great numbers of siliceous sponge spicules) alternate with calcareous (coccolithic) spongolites. No Oligocene, Miocene, and Pliocene deposits were found at Site 401 .

In Holes 400 and 402A (Figure 3; Plate 4, Figure 2), the sediments that represent a macrofacies similar to that described above overlie upper Albian deposits with a large stratigraphic break and are attributed only to the middle and upper Eocene (Cores 1 to 4, Hole 402A; Cores 4 and 5, Hole 402). They are represented by gray and greenish gray spongolites and coccolithic cement, and an admixture (in places) of clay material. There are interbeds of microbreccias from fragments of marls, organogenic limestones, and redeposited remains of echinoderms. Tests of foraminifers and diatom skeletons are sporadic. Small thin sponge spicules are arranged in the coccolithic mass, sometimes quite disorderly; in places, they show a tendency toward parallel orientation. No Oligocene, Miocene, and Pliocene deposits were recognized in Holes 401 or $402 \mathrm{~A}$.

Macrofacies of the deep-water oceanic sedimentation zone were formed under depositional conditions of mostly carbonate remains of zooplankton and phytoplankton. At Site 400 , this macrofacies covers the age interval from the uppermost Miocene to the lower Pleistocene. The uppermost parts of the Miocene and lower Pliocene are represented by pale, slightly greenish nannofossil oozes with tests of foraminifers. Sporadic silty particles of quartz and very rare remains of siliceous organisms are observed. The lamination is thin and horizontal. There are no middle or upper Pliocene deposits present.

Upper Pliocene deposits were found only in Holes 400 and $400 \mathrm{~A}$. These deposits are gray and dark gray clayey nannofossil oozes with tests of foraminifers and a variable admixture of unsorted sandy-silty material. The deposits are similar to Pleistocene sediments occurring higher up the section.

\section{Pleistocene Deposits}

Pleistocene deposits are developed throughout the interval (Figures 1 through 3; Plate 4, Figures 1 and 2). These are gray and brownish, slightly cemented, sandy-silty, clayey-calcareous oozes, sometimes with rare tests of foraminifers and indefinable shell detritus. Terrigenous material is compositionally diverse and unsorted within the sandy-silty fractions. Among fine-grained sand and silt particles, there is substantial quartz with some feldspar and mica. Coarse-grained sand fractions contain fragments of limestone and grains of quartz and hornblende. Pleistocene deposits belong to macrofacies of the deepwater oceanic sedimentation zone, the latter being characterized by a constant supply of ice-transported terrigenous material.

\section{Rockall Plateau}

In the Rockall Plateau region, Holes 403, 404, 405, and 406 of Leg 48 penetrated sediments ranging in age from early Eocene to the Pleistocene. A complete stratigraphic spectrum of deposits was not observed in any of these holes. Breaks in sedimentation, e.g., local and regional washouts, were recognized everywhere.

The stratigraphic interval in Rockall Plateau consists of rocks varying in lithology and genesis, and difficulties arise when correlating the sections. First, in the sections under comparison, there can be sediments with similar lithology but different age characteristics. Second, obviously synchronous deposits can be represented by quite different sediments in various sections.

\section{Eocene Deposits}

Eocene sedimentation in the area of Sites 405 (Figure 6) and 406 (Figure 7) was at a considerable distance from the shoreline and occurred initially in relatively deep water, then in a deep-water zone of the ocean. In the same period the accumulation of sedimentary materials in the area of Sites 403 (Figure 4) and 404 (Figure 5) proceeded under quite different conditions, i.e., predominantly a near-shore oceanic environment. This is of special interest, because this area is presently within the deep-water oceanic zone. In 


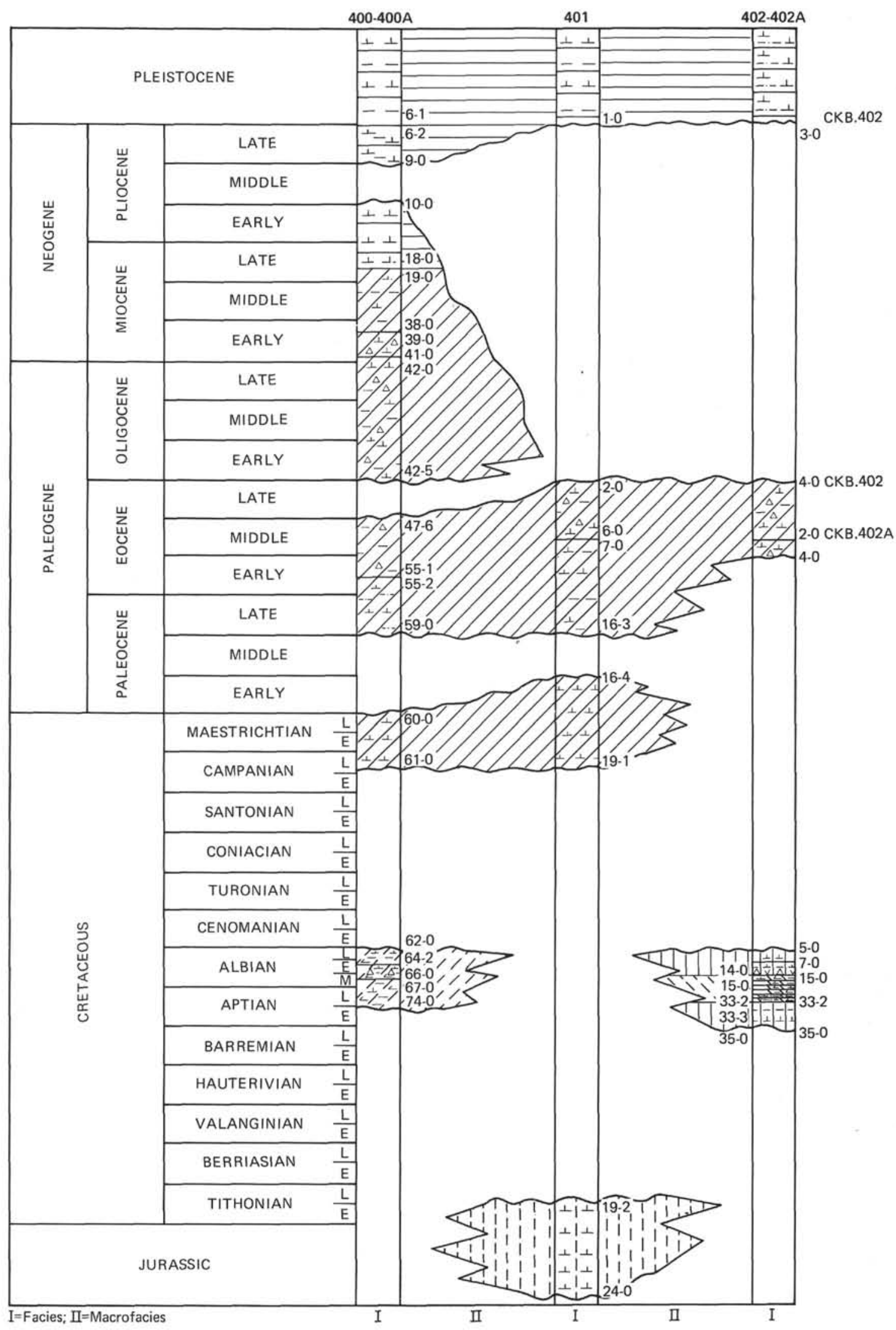

Figure 8. Diagrammatic facial section throughout Holes 400, 400A, 401, 402, and 402A of the Bay of Biscay, Leg 48. 


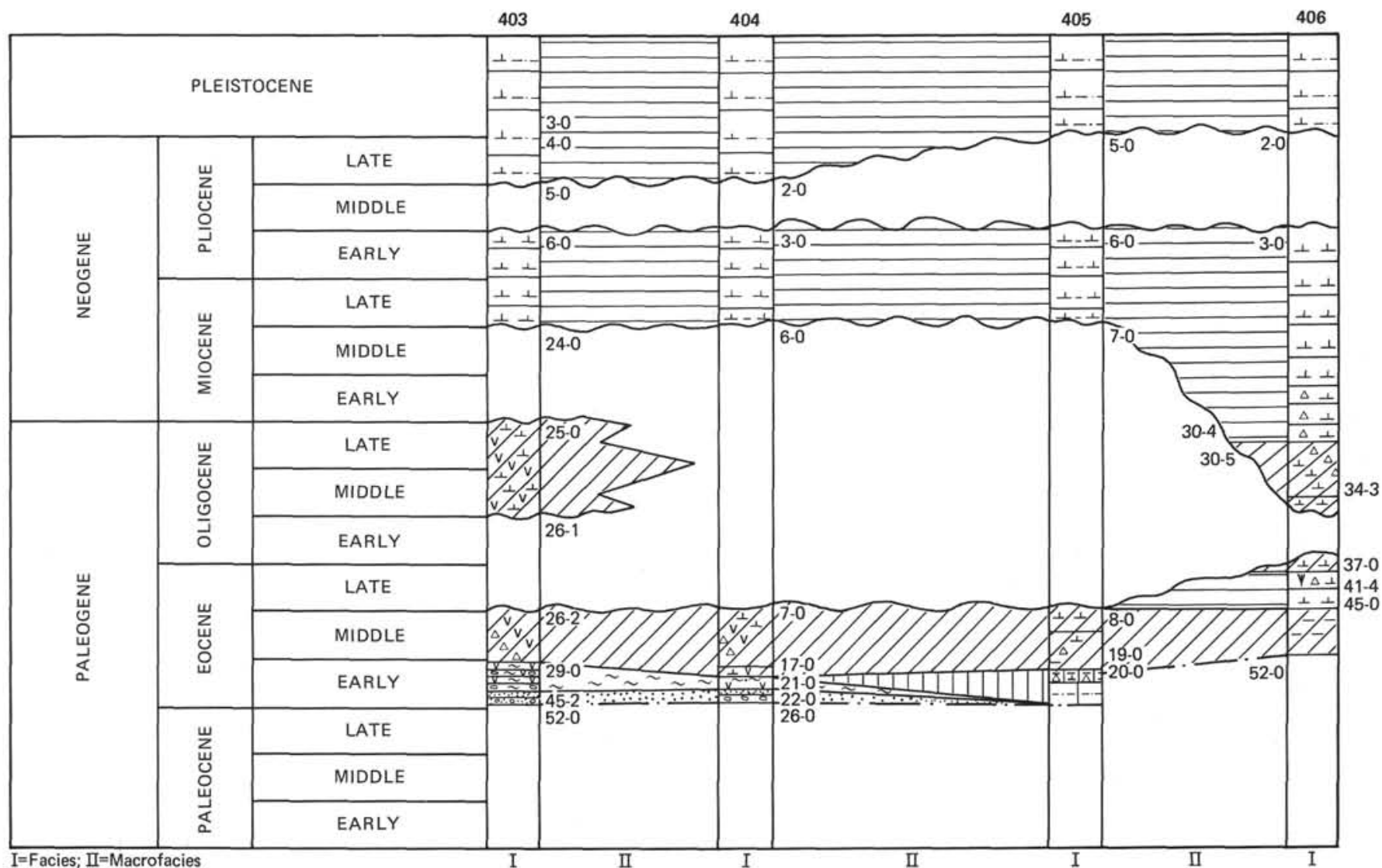

Figure 9. Diagrammatic facial section throughout Holes 403, 404, 405, and 406 of the Rockall Plateau, Leg 48.

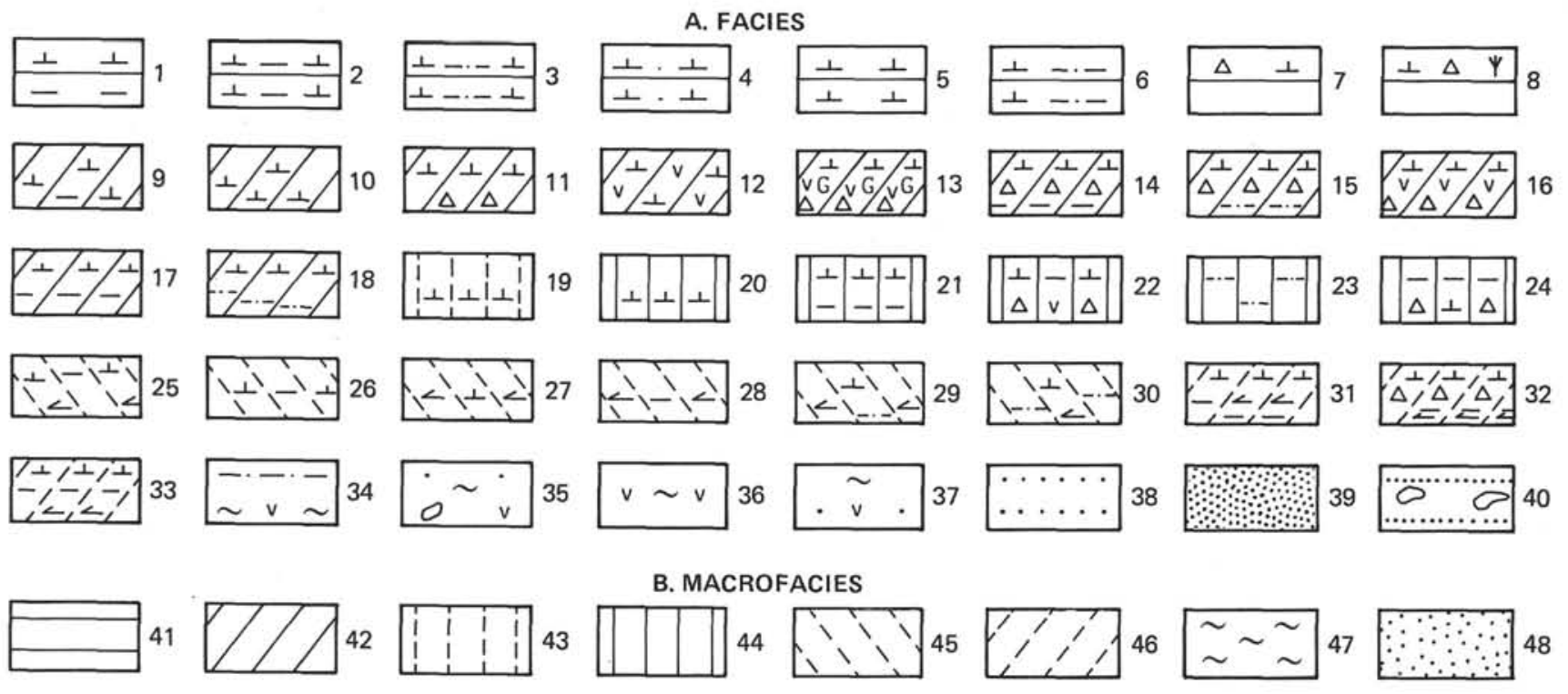

Legend for Figures 8 and 9. 
Holes 403 and 404, the lower and middle Eocene deposits are genetically related to the following three successive macrofacies: (1) zone of underwater deltaic sedimentation, (2) zone of near-shore oceanic mobile shallow-water sedimentation, and (3) zone of relatively shallow-water oceanic sedimentation.

The macrofacies of the underwater deltaic sedimentation zone is composed mostly of terrigenous gravel-sand-clay deposits with subordinate interbeds of pebbles and tephrogene rocks.

Sandy and coarser clastic rocks are gray and dark gray, whereas silty-clayey varieties are almost black due to abundant coaly detritus. Psephitic and psammitic sediments are characterized by well-sorted clastic material and oblique unidirectional lamination. Oblique series of laminae show evidence of slight washout, and differ from each other in grain size and angles of inclination. Silty deposits display fine crossbedding, in one or more directions, that interrupts horizontal lamination. The clastic depositional material of this macrofacies is extremely diverse. Among pebbles, gravel and sandy particles are rounded fragments of various effusives, metamorphic schists (micaceous-quartz-epidophytic), granite, and sedimentary rocks. The sandy-silty material contains grains of quartz, plagioclases, microcline, green hornblende, and biotite plates (altered to various degrees). Montmorillonite and calcite serve as cement in arenaceous and coarser detrital well-sorted sediments. The clay component of silty varieties is complex in composition. When judged by $\mathrm{X}$-ray diagrams of the fraction $<0.01 \mathrm{~mm}$, the following are clearly identifiable: montmorillonite, chlorite, and mixed-layer expanded chlorite-montmorillonitic mineral (apparently a product of diagenetic changes of terrigenous trioctahedral micas).

Tephrogene interbeds consist almost entirely of fragments of vesicular basaltic lava, usually unsorted and without traces of roundness, cemented by authigenic montmorillonite. Accumulations of authigenic zeolite are also present. Lava fragments are sometimes fresh and almost opaque, sometimes montmorillonitized to various degrees. Terrigenous grains of quartz, feldspars, and biotite plates are present in lesser amounts in tephrogene interbeds.

In Hole 403 (Figure 4), the underwater deltaic macrofacies (Section 45-2 to Core 52) can be subdivided into two facies. Gray, medium-grained, and fine-grained sandstones, firmly cemented by calcite, occur from Core 49 to the base of Hole 403. The sediments consist mainly of terrigenous polymictic, well-sorted clastic material, and are attributed to the fluvial channel facies of the underwater delta. From Section $45-2$ to Core 48 there are dark gray, fine-grained sandy and almost black clayey-silty rocks abounding in coal detritus. The sandy-silty fractions of these rocks are poorly sorted. These deposits probably accumulated under conditions of the peripheral part of an underwater delta. Within this drilled interval of Hole 403, there is an interbed of tephrogene rocks (Sample 46-1, $72-74 \mathrm{~cm}$ ).

In Hole 404 (Figure 5), the rocks genetically related to the underwater deltaic zone are traced from Cores 22 to 26; these rocks are similar to those of the same macrofacies in Hole 403. However, in Hole 404, the macrofacies is represented largely by coarser detrital material with a predominance of fragments (frequently well-rounded) of effusive rocks. The macrofacies is also subdivided into two facies. The lower 18 to 20 meters of the cored interval (Cores 24 to 26 ) belong to the facies of gravelly pebbled sediments of fluvial channels of the underwater delta. At the base of this facies, there are polymictic fine-pebbled conglomerates (Core 26) and coarse-grained sandstones. In Samples 23-6, 81-83 cm and 23-6, 50-54 cm of Hole 404, tephrogene interbeds are present. Above this section, as well as in Hole 403, they are replaced by facies of the peripheral part of the underwater deltaic sedimentation zone (Cores 22 and 23). These are dark gray, medium- and fine-grained sandy and silty rocks, with tephrogene interbeds (Section 23-4). Authigenic zeolite is peculiar to rocks of this facies, especially in Samples 22-2, 31-33 cm and $22-2,26-28 \mathrm{~cm}$.

The macrofacies of the near-shore shallow-water zone of Hole 403 is relatively thick (Core 29 to Section 45-1; Plate 2 , Figure 3). In Hole 404, its thickness is considerably less (e.g., Cores 18 to 21 ); they were probably heavily eroded. Deposits of this macrofacies consist of dark gray (nearly black with a greenish tint) clastic rocks of mostly sandy and silty varieties. There is much humic terrigenous material with constant levels of an admixture of lithoclastic and vitroclastic material. The lamination is horizontally wavy, interrupted, locally crossbedded, diversidirectional (due to the grain size of laminae), and emphasized by the arrangement of micaceous particles and coal detritus. Textures of roiling, traces of washout, and disturbances of primary lamination by burrows were recorded as well. Especially representative of the rocks of this macrofacies are two sharply differing types of clastic material, polymictic terrigenous and very uniform pyroclastic. The first type is predominant in sediments of the given macrofacies; an appreciable admixture of the second type occurs throughout the section. Also present are isolated tephrogene interbeds consisting exclusively of fragments of basaltic lava. Fragments of granite, micaceous schists, grains of quartz, feldspars, and plates of mica are observed among the terrigenous material. The pyroclastic material is represented mostly by fragments of basaltic lava, with grains of monoclinal pyroxene also present. The rocks of this macrofacies are characterized by authigenic zeolite and montmorillonite. The cement is complex. The terrigenous clay material originally was hydromica, chlorite, and ground biotite, together with colloidal humic matter. In diagenesis, montmorillonite became abundant, at the expense of pyroclastic material, and, in places, the mixed-layer phase montmorillonite-hydromica became common.

In Hole 403, the deposits of the given macrofacies are divided into four facies. At the base there occurs a fine-pebbled conglomerate with calcareous cement. It can be attributed to the facies of well-sorted and rounded gravelly, pebbled sediments, with an admixture of volcaniclastic material of the shallow-water zone (Sections 43-2 to 45-1). Further upsection (Core 41 to Section 43-1) there are deposits assigned to the facies of tephroid sediments of the shallow-water sedimentation zone in which there was an abundant supply of pyroclastic material. The tephrogene rocks are overlain again by normal sedimentary 
rocks (Cores 31 to 40 ). In the lower part of the cored interval, there is frequent alteration of silty sediments, more argillaceous or arenaceous in different places. The quantity of arenaceous material increases uphole, and silty rocks are replaced by sandstones of various grain sizes. These deposits belong to the sandy and silty-clayey facies that are rich in pyroclastic material, i.e., sediments of the mobile shallow-water sedimentation zone. The section is capped with a tephrogene layer (Cores 29 and 30), the accumulation of which is related to the facies of tephroid sediments of the mobile shallow-water sedimentation zone.

In Hole 404, the facies of sandy-silty sediments remained preserved only after washout with an admixture of volcanogenic material of the near-shore mobile shallow-water zone.

Thus, in Holes 403 and 404, two macrofacies that comprise the lower part of the Eocene contain sediments accumulated in the near-shore zones of the ocean. River waters transported abundant clastic material of polymictic composition from land sources. Significant amounts of plant detritus and colloidal humic matter were supplied, together with mineral clastic material. Humid condition and dense vegetation cover probably existed at that time on the coast. The presence of fresh reactive humic matter in sediments controlled the character of their diagenesis. The processes of oxidation of humus resulted in increased $\mathrm{CO}_{2}$, and thus, in high solubility of carbonate; i.e., chemical precipitation of calcite was presented, resulting in the sandy-silty-clayey sediments of these macrofacies being almost devoid of organogenic carbonate remains and lacking any authigenic clacite. Sporadic foraminiferal tests and tiny coccoliths are extremely rare. Interbeds with calcitic cement can be observed only among arenaceous and coarser clastic rocks, the original sediments of which were washed from clay and humic material. Remains of calcareous organisms are not observed frequently in tephrogene rocks, but the low carbonate content of these rocks occurred because tephrogene material accumulated so rapidly it interfered with the precipitation of other components of the sediments (terrigenous and organogenic).

The formation of deposits of the above macrofacies proceeded in a seismically active area proximal to active volcanoes. Basaltic magma erupted and supplied vitroclastic material and, to a lesser extent, crystallo-lithoclastic material. During the intensification of tectonic movements, some older volcanic structures were thoroughly eroded, then transformed into a local oceanic source of clastic material. Tephrogene beds with unsorted, poorly (if at all) rounded material of very uniform composition was formed, i.e., fragments of basaltic lava montmorillonitized to various degrees.

The macrofacies of sediments of a relatively deep-water oceanic sedimentation zone from Holes 403 and 404 includes deposits markedly different (both in appearance and material composition) from those below the macrofacies. The macrofacies is composed of pale gray and greenish gray tuffogenous organogenic rocks, varying in different places from containing more carbonate to essentially siliceous. Terrigenous clastic material is not representative; humic matter and plant detritus are entirely absent. The deposits of this macrofacies are characterized by frequent occurrences and occasionally abundant amounts of authigenic glauconite and mixed-layer phase hydromica-montmorillonite. Zeolite is constant. According to $\mathrm{X}$-ray data, cristobalite is common and tridymite is sometimes observed. Pyroclastic material is represented mostly by fragments of volcanic glass and lesser amounts of crystalloclastic and vitroclastic material (pyroxene, plagioclases, fragments of the groundmass of basalts, andesites, and andesite-dacite). Volcanic glasses are of various basicity. Fragments of colorless acid glasses are predominant, but there are also dark (green and brown) fragments of the basaltic series. Carbonate is present as tests of foraminifers and coccoliths. Biogenic silica is represented by fragments of siliceous sponge spicules and diatom skeletons. Glauconite, which is bright green with dotted polarization, yields shapeless clusters with smooth contours, open fissures of syneresis, or small globules. Diffractograms usually show hydromica, but with packets of montmorillonite. The mixed-layer phase hydromicamontmorillonite is widely distributed. This glauconite- like mass penetrates into canals of sponge spicules, fills the chambers of some foraminifers, provides pseudomorphs on some diatom skeletons, and unevenly colors the cementing mass of rocks. The cementing mass is not uniform, consisting of coccoliths, amorphous opal, and thin scales of montmorillonitic matter.

The above-mentioned macrofacies is most fully represented in Cores 7 to 17 of Hole 404. In Hole 403, its deposits are thoroughly washed out, their thickness being relatively insignificant (Cores 27 and 28).

The lower boundary of deposits of this macrofacies is well pronounced; it occurs on the washed surface of the series of near-shore shallow-water sediments. One gets the impression that the new sedimentation cycle did not begin simultaneously everywhere. Therefore, the denuded surface of the lower deposits was overlain by horizons of a new series differing in age. Thus, in Hole 404, the deposits of almost the whole facies belong to lower Eocene strata; in Hole 403, similar (but not identical) deposits are middle Eocene. It is likely that almost no direct analogies of middle Eocene deposits in Hole 404 remain preserved; the overlying, much younger series of deposits transgressively rests with a large break.

In Hole 404, Eocene deposits of the relatively deep-water oceanic zone can be subdivided into two facies. The lower facies (Cores 11 to 17) is identified as tephrogene organo-carbonate-siliceous sediments. Besides lithoclastic and vitroclastic material, the deposits of this facies contain considerable amounts of siliceous organic remains (mostly diatoms, or diatoms and sponge spicules), with small amounts of organogenic carbonate (coccoliths, foraminifers) always present. The rocks of this facies are interpreted as either slightly calcareous diatomites or slightly calcareous spongolite-diatomites. Authigenic glauconite-like matter and pyroclastic material are recognized everywhere.

The upper facies (Cores 7 to 10; Plate 3, Figure 4) is of tuffogenic organogeno-siliceous sediments. In contrast to the previous facies, it contains almost no remains of calcareous organisms (sporadic foraminiferal tests), and litho-vitroclastic material is submerged into the organogenic siliceous (spongolite-diatomitic) mass. In some interbeds 
(Core 8), pyroclastic material is especially abundant. Authigenic glauconite-like matter can be recognized throughout the facies.

The rock occurring at the upper boundary of the given facies (Core 7) is an exception. This is a tuffogenic organo-carbonate-siliceous sediment with abundant authigenic glauconite. Along with remains of siliceous organisms, there are many coccoliths and foraminiferal tests here. It should be noted that these deposits also differ in age from the underlying ones, and are attributed to the middle Eocene. They are lithologically similar to middle Eocene deposits of Hole 403.

In Hole 403, the macrofacies of sediments of a relatively deep-water oceanic sedimentation zone belong to the Eocene and includes one facies of tuffogenous organocarbonate-siliceous sediments (Section 26-2 to Core 28; Plate 3, Figure 3). These deposits contain abundant authigenic glauconite and mixed-layer phase hydromica-montmorillonite. Silty particles of quartz and feldspars are present, as well as zeolite. In Core 28 , there is an interbed of foraminiferal marl with remains of siliceous organisms. In the uppermost part of the facies, is a thin interbed (Sample $27-1,23$ to $25 \mathrm{~cm}$ ) of vitroclastic tuff of median composition. Pale green glass fragments of silty grain size are cemented by montmorillonite; in some places, there are relics of foraminiferal tests.

The low content of mineral terrigenous material and the absence of allochthonous plant detritus and humic matter testify to a rather long distance between the sedimentation zone of these sediments and the shoreline. This zone was probably already transformed into a relatively deep-water area. A continuous and abundant supply of volcanogenic material into this region apparently served as an additional source of nutrients for plankton. As a result, the diatom flora flourished in the surface waters, with high productivity and heavy precipitation of numerous skeletal parts of diatoms.

Various diagenetic processes actively proceeded in these deposits. The basic and median volcanic glasses decomposed; montmorillonite, a mixed-layer hydromicaceousmontmorillonitic component, glauconite, and zeolite formed, and carbonate and organogenic silica were partially dissolved. The carbonate and organogenic silica were redeposited and precipitated as globular opal. Authigenic glauconite-like matter is frequently associated with biogenic remains, filling chambers of foraminiferal tests and forming pseudomorphs on diatom skeletons. These organic remains likely fell into a sediment with incompletely decomposed plasma that, during diagenesis, was involved in the processes of authigenic mineral formation.

In Holes 405 (Figure 6) and 406 (Figure 7), Eocene deposits are represented by rocks that are uniform in appearance; they are clay-organogenic, sometimes strongly calcareous or significantly siliceous. Sediments with an appreciable admixture of silty particles occur in smaller amounts. Arenaceous and coarser clastic terrigenous deposits are not present here. Neither tephrogene interbeds nor interbeds enriched in pyroclastic material were recognized in this cored interval.

The sections from Hole 405 and 406 in the given age interval are not fully correlated with one another. The sediments in Hole 405 belong to the lower and middle Eocene and, in Hole 406, to the middle and upper Eocene.

In Hole 405, the thickest part of the lower Eocene deposits (Cores 20 to 43 ) is genetically related to the macrofacies of the relatively shallow-water oceanic sedimentation zone, and only a small part of these deposits (Cores 15 to 19) is attributed to macrofacies of a relatively deep-water oceanic sedimentation zone. By mode of accumulation, the middle Eocene deposits (Cores 8 to 14) wholly belong to the macrofacies of a relatively deep-water oceanic sedimentation zone.

In Hole 405, macrofacies of sediments of the relatively shallow-water oceanic sedimentation zone is divided into two facies. The lower part of the section (Cores 32 to 43; Plate 2, Figure 1) corresponds to the facies of silty-clayey sediments, and is composed of silty marls with rare foraminiferal tests, diatom skeletons, and siliceous sponge spicules. Interbeds of calcareous clay with axially oriented clay particles also were recognized. The lamination is thin, horizontal, in places horizontally wavy and microlenseshaped; less frequently, lamination is small, cross, and flattened. Some interbeds contain inclusions of large fragments of pale green montmorillonitic. These fragments appear to have been transported by currents from zones of shallower water, where montmorillonitized tuffogenic sediments were subjected to partial washout. Higher up (Cores 20 to 31 ), the amount of silty material decreases, and deposits of another facies (clay organogenic-carbonatesiliceous sediments) become predominant. Fragments of green montmorillonitic can be observed in the sediments. The lamination is thin, horizontal, horizontally wavy, and lense-shaped. The rocks of this facies are characterized by the presence of cristobalite and tridymite that can be discerned through X-ray analysis. Coal dust was observed everywhere.

Lower Eocene deposits in Hole 405 are crowned with calcareous diatomites (Cores 15 to 19). These are rather uniform, biogenic, essentially siliceous sediments. They consist mostly of diatom skeletons (unbroken and crushed). Foraminiferal tests and coccoliths are present throughout the section, with small lense-shaped accumulations of clay matter observed as well.

Textures of roiling and sliding were recorded. In some interbeds of diatomites, there are small fragments of thin siliceous sponge spicules. Clinoptilolite can be found occasionally by means of X-ray analysis. Calcareous diatomites are attributed to the macrofacies of sediments of a relatively deep-water oceanic zone, and probably originated from facies of organogenic-calcareous-siliceous sediments.

Middle Eocene deposits in Hole 405 are not thick (Cores 8-14) compared to lower Eocene deposits. The lower part of these deposits (Cores 12 to 14) is composed of the same calcareous diatomites; i.e., it is genetically related to the above facies. The upper part of middle Eocene deposits (Cores 8 to 11) is represented by loose nannofossil/ foraminiferal oozes with a very small admixture of remains of siliceous microorganisms, their numbers decreasing uphole. There are nannofossil/foraminiferal oozes without traces of organogenic silica in Cores 8 and 9, with an occasional small admixture of fragments of volcanic 
glasses. X-ray analysis enabled us to identify clinoptilolite. The accumulation of these organogenic-carbonate sediments should be related to the macrofacies of the relatively deep-water oceanic sedimentation zone.

In Hole 406 (Figure 7), middle Eocene deposits (Cores 46 to 52) are represented by coccolithic marls; the lamination is thin and horizontal. Small foraminiferal tests are rarely dispersed in the ground coccolithic mass; diatom skeletons are visible from place to place; there is an admixture of coal dust. The clay matter is in a fine mixture with the coccolithic mass, and also forms microscopic lenses stretching along laminations. Small aggregates of authigenic pyrite also can be observed. Some interbeds contain inclusions of fragments of the montmorillonitic mass. These deposits belong to the facies of organogeniccarbonate-clayey sediments, macrofacies of relatively deep-water oceanic sedimentation zone. The deposits of the given facies are crowned with a thin layer (Sections 46-1 to 46-2) of a rock which differs sharply from deposits lying below. This layer is dark brown, slightly calcareous clay with thin horizontal lamination emphasized by an oriented arrangement of clay particles. The rock is evenly saturated with iron hydroxides.

As already emphasized, upper Eocene deposits are fixed in Hole 406 (Figure 7), but are absent in the other holes. These deposits are purely biogenic. The lower part of the cored interval (Section 41-5 to Core 45 ) is composed of coccolith-foraminiferal sediments. Some areas abound in tests ranging from large to small at different levels. Inclusions of green montmorillonitic (fragments of altered tuffs) are frequent. According to X-ray data, there are cristobalite and tridymite. From Sections 40-2 to 41-5, there are interbeds of microbreccias consisting of fragments of foraminiferal marls and montmorillonitized tuffs (local material). The upper part of Eocene deposits (Cores 38 and 39) is characterized by abundant remains of gigantic diatoms, i.e., Ethmodiscus. In some interbeds, the remains of these algae make up the ground mass of the sediment, admixed with foraminiferal tests, small diatom skeletons, thin spicules of siliceous sponges, coccoliths, and fragments of acid volcanic glass. The oriented arrangement of Ethmodiscus contribute to the horizontal lamination and explain their lamelliform structure. The bedding planes present a pearly luster. Noteworthy is that in Recent sediments of the Atlantic Ocean no accumulation of Ethmodiscus remains has been found.

The observation of other researchers (Lisitsin, 1974) is that the accumulation of Ethmodiscus skeletons in sediments are presently confined to the equatorial belt of the Pacific Ocean and peculiar to sedimentation in deep basins.

\section{Oligocene Deposits}

Lower Oligocene deposits were not recorded in any of the sections studied. Part of the middle and upper Oligocene sediments remain after washout in Hole 403. The sediments are most fully represented in Hole 406 . In both cases, these deposits owe their origin to macrofacies of the relatively deep-water oceanic sedimentation zone under conditions of continuous supply of (in places abundant) biogenic silica and appreciable portions of vitroclastic and clastic material.
In Hole 403 (Figure 4), Oligocene deposits were recognized in Sections $25-0$ to $26-1(\approx 13 \mathrm{~m})$. They are composed of foraminiferal/nannofossil sediments containing an admixture of small fragments of acid volcanic glass.

In Hole 406 (Figure 7), Oligocene deposits begin from Section 36-2 and are traced upwards to Core $28(\approx 72 \mathrm{~m})$. These deposits are subdivided into three facies. The lower facies (Sections 34-4 to 36-2) includes organogenic carbonate sediments: nannofossil-foraminiferal with an admixture of diatoms, and siliceous sponge spicules (almost entirely transformed into cristobalite). The presence of fragments of montmorillonitic, rather abundant in places, basalt and local rocks (nannofossil marls) is representative. Chambers contain foraminiferal-authigenic montmorillonite. The middle facies (Sections 30-5 to 34-3) is represented by organogenic siliceous-carbonate sediments (coccolithic and foraminiferal), with an appreciable constant admixture of biogenic silica. The upper facies of sediments (Core 28 to Section 30-4) is characterized by algal Ethmodiscus oozes similar to those composing the Upper Eocene deposits.

\section{Miocene Deposits}

Lower Miocene deposits were recorded in Hole 406 only (Figure 7). They directly overlie upper Oligocene deposits, and retain the lithological characteristics of the lower part of the latter (Section 34-3 to Core 27; Plate 4, Figure 4).

Middle Miocene deposits (Core 16 to Section 24-2) is composed of foraminiferal-nannofossil oozes with an admixture of organogenic silica (the latter not prevailing).

Lower and middle Miocene deposits belong to the macrofacies of a deep-water oceanic sedimentation zone under coditions of precipitation of carbonate and siliceous organic remains.

Upper Miocene deposits are well distributed and are represented by monotypic coccolith-foraminiferal and foraminiferal-coccolithic oozes. There are no siliceous organisms; fragments of volcanic glass are rare. The great variety of these rocks is caused by quantitative relationships between foraminiferal tests and coccolithic groundmass, sorted according to size of foraminiferal tests, and to the character of their lamination.

Upper Miocene deposits are peculiar to the macrofacies of the deep-water oceanic sedimentation zone under conditions of deposition of mostly carbonate sediments of zooplankton and phytoplankton.

\section{Pliocene Deposits}

Lower Pliocene deposits occur throughout the sections, but no middle Pliocene deposits were recognized. The upper Pliocene sediments discerned only in Holes 403 and 404, are uniform and analogous to Miocene sediments. They are composed of nannofossil-foraminiferal, foraminiferal and foraminiferal-nannofossil oozes, the accumulation of which took place under conditions of macrofacies of a deep-water oceanic sedimentation zone. Upper Pliocene oozes contain inclusions of sporadic quartz sand grains, feldspars, and gravelly pebbled fragments of various rocks.

\section{Pleistocene Deposits}

Pleistocene deposits are well distributed and represented by gray, brownish and (in some interbeds) almost white 
foraminiferal oozes. These oozes have a constant, sometimes very abundant admixture of unsorted terrigenous material: clayey, sandy-silty, pebbled, and even boulders. The clay matter of these sediments is polymineral; hydromicas are predominant, with chlorite, kaolinite, and montmorillonite present as well. The clastic material is diverse with grains of quartz, feldspars, mica plates (biotite and muscovite), quartz-epidotic aggregates, fragments of granite and micaceous shales, pieces of coaly, clayey and marly rocks, acid effusives, and basalts. The heavy minerals include grains of garnet, pyroxene, and hornblende.

Pleistocene deposits accumulated in the same deep-water oceanic zone as Pliocene sediments, but with systematic contamination of foraminiferal oozes by ice transported terrigenous material.

\section{RESULTS}

Detailed lithofacies analysis of structure and composition of Mesozoic-Cenozoic (including Aptian-Albian "black shales"') and Quaternary deposits of the Bay of Biscay and Rockall Plateau, based on Leg 48 cores, enables the following brief conclusions on the history of sedimentation and geological development of these regions. For this purpose, we compiled diagrammatic facies sections, Figures 8 and 9. Study of cores recovered from adjacent regions (Legs 38, 41, 45, and 49) permits consideration of the North Atlantic as a whole.

1) Synchronous sedimentation developed differently in the two regions. The region of the Rockall Plateau turned into the deep-water oceanic zone later than did the Bay of Biscay. In the lower and middle Eocene of the Rockall Plateau, there was a shallow-water and even near-shore shallow-water oceanic environment of sedimentation. In the Bay of Biscay region, the sediment accumulation was already underway in a relatively deep-water part of the ocean. Similar conditions of sediment accumulation in both regions have occurred since approximately the Oligocene, in the relatively deep-water environment of sedimentation, and then, from the late Miocene time, when the deep-water environment began.

2) In the Rockall Plateau region, the tectonic plate movements were less intense than those in the Bay of Biscay. The upper Miocene and lower Pliocene sediments in the Rockall Plateau area were deposited in greater quantities and over a more extensive area.

3) The Eocene-middle Miocene period was characterized by flourishing diatom floras in the surface waters of the ocean and by the development of sponge colonies. Sediments of this period are enriched in biogenic silica. Beginning from the late Miocene, the role of biogenic $\mathrm{SiO}_{2}$ in sediments became negligible, and purely carbonate sediments accumulated in the deep-water oceanic zone. Pleistocene sedimentation in both regions proceeded in a deep-water oceanic zone with the terrigenous supply transported by ice, then transformed into nannofossilforaminiferal oozes. In deposits of the Rockall Plateau region, the terrigenous admixture is abundant and unsorted in terms of grain size; besides clay-silty and sandy material, there is gravel, pebbles, boulders. In the Bay of Biscay region, the terrigenous admixture in Pleistocene deposits usually consists of clayey, silty, sandy particles. More so than the Bay of Biscay region, the Rockall Plateau region was probably more accessible to iceberg traffic. Icebergs probably approached the Bay of Biscay region less frequently, and a common agent of transportation of terrigenous material to this area was drift ice of a lesser scale.

4) In the Eocene, the Rockall Plateau sector was relatively near the areas of active volcanoes; tephrogene and pyrogenic (lithoclastic and vitroclastic) material made up a major part of the sedimentary accumulation of that time. Fresh ashy material present in the sediments was responsible for the great variety of their post-depositional diagenesis. Basaltic pyroclastic material plays an important role in the composition of lower Eocene sediments and, in middle Eocene sediments, the influence of andesite-basaltic and andesitic material is evident. The Bay of Biscay region was distal from the areas of active volcanism, and only fine vitroclastic material was transported there.

5) Post-depositional changes of the sediments proceeded within varying parameters of course and rate. Partial solution of biogenic carbonate and silica occurred and chemically redeposited, and fresh biotite plates were transformed onto trioctahedral hydromicas. Fragments of volcanic glass decomposed; authigenic zeolites, montmorillonite, and mixed-layer montmorillonite-hydromicaceous phases appeared, and, in some places, glauconite was formed. In rocks of Eocene age and older, the primary organogenic opal was partially, and in some places (e.g., in Aptian sediments) entirely, transformed into cristobalite.

6) Both regions are presently in a deep-water oceanic environment. Almost all DSDP holes were drilled in water depths of 1300 to 3000 meters, with Site 400 drilled in over 4000 meters of water. The oceanic bottom is covered everywhere by thin (from 10 to $100 \mathrm{~m}$ ) Pleistocene deposits.

7) Although in neither of the regions was the basement reached during drilling, the pre-Quaternary deposits under study in both regions are very similar in thickness. However, they differ significantly as to their age. In the region of the Bay of Biscay, the sedimentary interval covers a wide age interval, from the Upper Jurassic to the Pleistocene. In the Rockall Plateau region, the sedimentary deposits of the same thicknesses, in general, have a much younger age. The oldest horizons of these deposits are dated as lower Eocene.

8) Examination of Figures 8 and 9 shows that the sediments do not represent an uninterrupted temporal progression at the drillsites of either region. Discontinuities, both regional and local, are apparent in both regions.

One of the main reasons for the interrupted accumulation is the high rate of tectonic activity that occurred in the regions concerned. During sedimentation the tectonic blocks in these areas underwent disjunctive movements that differ in time, rate, and amplitude. These movements withdrew some blocks from the sphere of sedimentary accumulation, or provided (by means of constant and intense subsidence) almost continuous accumulation. The corresponding relief of the oceanic bottom contributed to uneven distribution of sediments differing in age and thickness. Intense sedimentation that was seldom interrupted proceeded in the basins. On rises, the sediments 
either did not accumulate at all, accumulated but did not endure, or accumulated in relatively thin layers. Bottom currents and turbulent flows rarely favored the burial of sediments.

9) Tectonic movements (and the morphology of the oceanic bottom controlled by them) and sometimes currents determined the course of the processes of sediment accumulation. The distribution of major tectonic blocks and principal elements of the underwater relief changed slowly. Therefore, the sedimentation of the rises proceeded irregularly and with large breaks; in areas of intense subsidences, there was thick and stratigraphically more complete accumulation. This can be observed in the cores from Sites 400 and 401 of the Bay of Biscay and from Sites 405 and 406 of the Rockall Plateau. Sites 401 and 405 reflect a history of sedimentation which at various times was excluded from the zone of sedimentary accumulation; these areas underwent ascending movements.

10) Finally, the above-mentioned provides a sound basis for the preliminary study conclusion that the North Atlantic Ocean, as we now know it, most probably did not exist in the Jurassic and in a greater part of the Cretaceous periods. In its place, there was a series of both isolated and interconnected shallow-water marine basins of various extent and depth. The North Atlantic Ocean began forming at the end of Cretaceous and the beginning of Paleogene, somewhat earlier in the west than in the east, and spread from the south towards the north, as evidenced by the development of relatively deep-water nannofossil/ foraminiferal sediments. The known cases of occurrences of "black shales", directly on rocks of the oceanic crust by no means speak of their accumulation at great depths. Break and separation of the continental crust could have taken place not long before accumulation of "'black shales.' Had it happened much earlier, the rocks of the oceanic crust would likely have been beyond the zone of accumulation and would represent a land.

The active tectonic movements related to the Alpine orogenic stage controlled the process of uniting the separated basins of sedimentation. The further separation and subsidence of vast territories of the American, European, and African continents resulted in the establishment of the North Atlantic Ocean. Block movements, differentiated and differing in sign and intensity, as well as the rising of the Mid-Atlantic Ridge, were responsible for the present complicated nature of sediment accumulation in these areas under study.

\section{REFERENCES}

Khvorova, I.V., 1958. Atlas of middle and upper Carboniferous carbonate rocks of the Russian platform: Moscow (Izdat. Akad. Nauk SSSR).

Lisitsin, A.P., 1974. Sediment formation in the oceans (quantitative distribution of sedimentary material): Moscow (Nauka).

Strakhov, N.M., 1951. Calcareous-dolomite facies of recent and old basins, Trudy GIN Akad. Nauk SSSR., v. 124, no. 45.

Timofeev, P.P., 1968. Lithologo-facies and formational analysis of coal-bearing deposits. Report of the Twenty-Third Session, Czechoslovakia, 1968. Proceedings of Section 11 Origin of Coal Deposits International Geological Congress. Academia, Prague.

1969. Geology and facies of the Jurassic coal-bearing formation in southern Siberia, Trudy GIN Akad. Nauk SSSR, v. 197.

, 1970. Jurassic coal-bearing formation of southern Siberia and conditions of its formation, Trudy GIN Akad. Nauk SSSR, v. 198.

, 1972. Coal-bearing formations and their role for cognizing the sedimentary process, Litologiya i poleznie iskopaemie, no. 3 . 


\section{PLATE 1}

Macrofacies Sediments of the Near-Shore Marine Shallow-Water Zone

Figure $1 \quad$ Facies calcareous-silty-siliceous-clayey sediments with an admixture of humic and sapropelic-humic material of the near-shore oceanic shallow-water zone. Dark gray clayey chalk with interbeds of sapropelic-humic material (A). Sample 402A-16-2, $40-60 \mathrm{~cm}$.

Figure 2 Facies marly sediments with an admixture of sapropelic material of the near-shore oceanic zone. Nannofossil/foraminiferal marl with interbeds enriched in humic-sapropelic matter (A). Sample $400 \mathrm{~A}-62-3,50-70 \mathrm{~cm}$.

Figure 3 Facies marly sediments with an admixture of sapropelic material of the near-shore oceanic zone. Nannofossil/foraminiferal marl with horizontal lamination (A). Sample 400A-62-4, 65-85 cm. 


\section{PLATE 1}
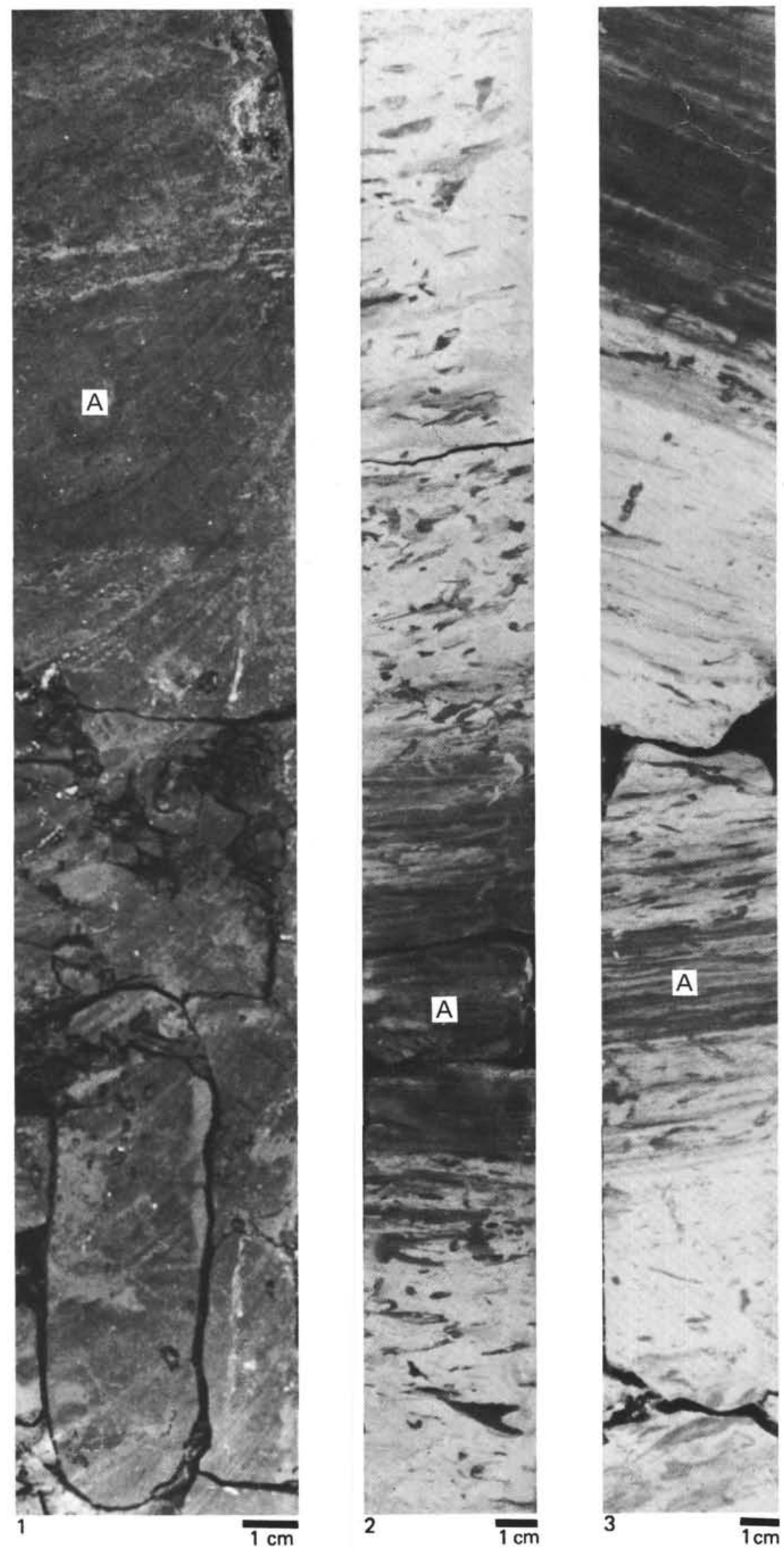


\section{PLATE 2}

Microfacies Sediments of the Relatively Shallow-Water Marine Zone

Figure 1 Facies of silty clayey sediments of the relatively shallow-water zone. Greenish gray compact siltstones with thin horizontal lamination (A). Sample 405-37-2, 50-70 cm.

Figure 2 Facies of calcareous-siliceous-silty-clayey sediments with an admixture of tuffogene material of the relatively shallow-water zone. Calcareous-siliceous tuffogene with silty-clayey admixture, dark gray at the expense of humic material (A), rare burrows (B). Sample 402A-13-1, 15-30 cm.

Figure 3 Facies of sandy-silty-clayey sediments with abundant pyroclastic material of the near-shore oceanic shallow-water zone. Coarse and medium-grained, dark green sandstones with small cross convergent lamination (A). Sample 403-34-5, 80-100 cm. 
PLATE 2
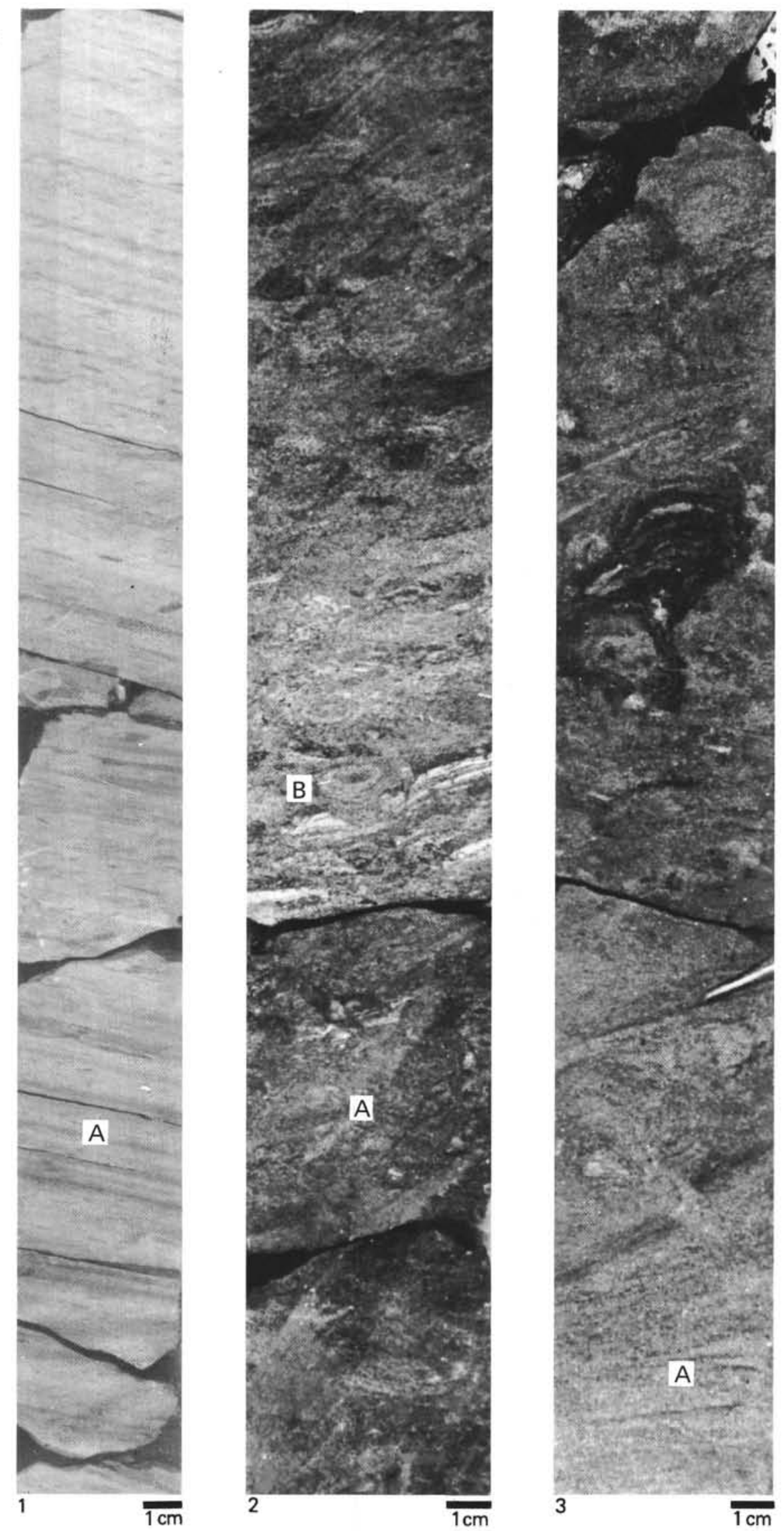


\section{PLATE 3}

Macrofacies Sediments of the Relatively Deep-Water Oceanic Zone

Figure 1

Facies of organogenic and clay-organogenic sediments of the relatively deep-water zone. Pale gray marly nannofossil chalk with interbeds of clay material (A), rare burrows (B). Sample 400A-37-4, $90-120 \mathrm{~cm}$.

Figure 2 Facies of organogenic-carbonate sediments of the relatively deep-water zone. Nannofossil chalk of yellowish orange color with horizontally wavy lamination (A). Sample 401-16-2, 130-150 cm.

Figure 3 Facies of tuffogene organogenic-carbonate-siliceous sediments of the relatively deep-water zone. Carbonate siliceous tuff with horizontally wavy lamination (A). Sample 403-28-1, 40-60 cm.

Figure $4 \quad$ Facies of tuffogenic-organogenic-siliceous sediments with authigenic glauconite of the relatively deep-water zone. Spongolite diatomic with small striated cross-lamination (A), rare burrows (B). Sample 404-7-2, 85-100 cm. 
PLATE 3
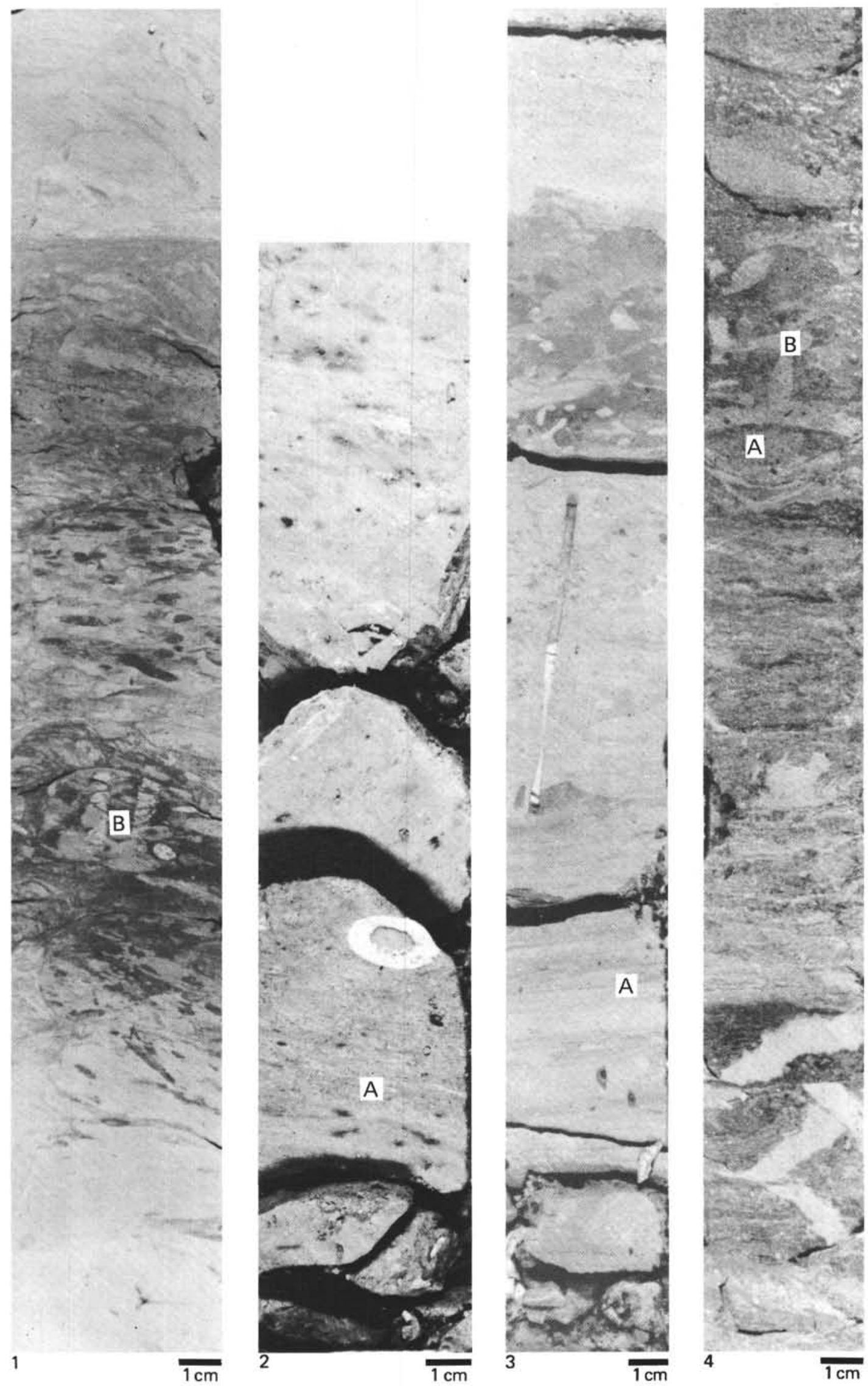


\section{PLATE 4}

Macrofacies Sediments of the Deep-Water Oceanic Zone

Figure 1 Facies alternation of organogenic (A) and clayey (B) sediments with an admixture of clay material of the deep-water zone. Pale gray marly nannofossil oozes with relics of horizontal laminations (C). Sample 400A-3-2, 45-70 cm.

Figure 2 Facies of organogenic-silty clay sediments of the deep-water zone. Pale gray nannofossil oozes horizontally laminated (A) with an admixture of silty-clayey material. Sample 402-89-5, 5-50 cm.

Figure 3 Facies of organogenic-carbonate sediments of the deep-water zone. Foraminiferal/nannofossil chalk with diatom skeletons, sponge spicules, and thin horizontal lamination (A). Sample 406-25-1, $0-40 \mathrm{~cm}$. 
PLATE 4
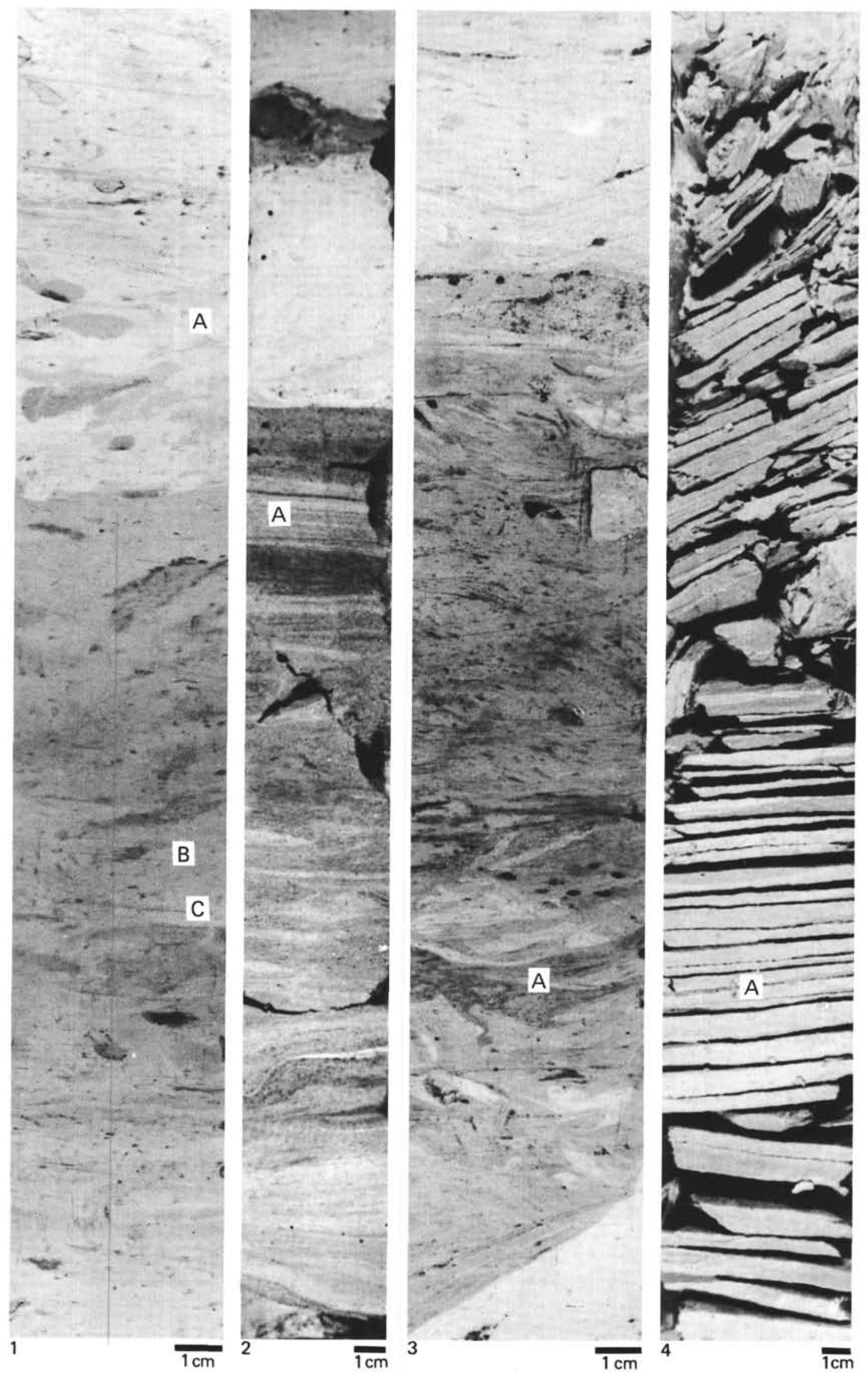